\title{
LEPTOSPIRES DETECTION IN KIDNEY, LIVER AND UTERUS OF COWS SLAUGHTERED IN PARANÁ STATE, BRAZIL
}

\author{
Francielle Gibson da Silva ${ }^{1}$; Julio Cesar de Freitas ${ }^{1 *}$; Eleine Kuroki Anzai ${ }^{1}$; Vanessa Yumi Hashimoto ${ }^{1}$; \\ Nilson Giraldi²; Ádina Cléia B. Delbem²${ }^{2}$; Ana Paula F.R.L. Bracarense ${ }^{1}$; Antônio Carlos F. dos Reis ${ }^{1}$; \\ Silvio Arruda Vasconcellos ${ }^{2}$
}

${ }^{1}$ Universidade Estadual de Londrina, Centro de Ciências Agrárias, Departamento de Medicina Veterinária Preventiva, Londrina, PR, Brasil; ${ }^{2}$ Universidade de São Paulo, Faculdade de Medicina Veterinária e Zootecnia, Departamento de Medicina Veterinária Preventiva e Saúde Animal, São Paulo, SP, Brasil

Submitted: August 08, 2003; Returned to authors for corrections: October 14, 2004; Approved: March 03, 2005

\begin{abstract}
The objective of this trial was to detect leptospires in fragments of kidney, liver and uterus of 96 cows with unknown sanitary status, randomly chosen at slaughter in Paraná, Brazil. All 96 urine samples were submitted to direct examination using dark field microscopy. Positive samples in the direct examination and all kidney, liver and uterus fragments were cultured in EMJH modified medium and Tween 80/40/LH. Sections cut of kidney, liver and uterus were stained by Hematoxylin-Eosin (HE) and indirect immunoperoxidase with hyperimmune serum against serovar Hardjo (Hardjoprajitno) and strain Londrina 14 (LO14), from serovar Canicola, which was isolated in the northern region of Paraná state, Brazil, used as primary antibodies. Direct examination detected leptospires in the urine of four animals. All attempts to isolate leptospires from urine and kidney, liver and uterus fragments were negative after 16 weeks of incubation. In the HE stain, focal infiltrate of mononuclear inflammatory cells was observed in the renal interstitial area of most animals. In the indirect immunoperoxidase assay using hyperimmune serum against LO14 strain, the kidney of only one animal presented positive results. All fragments of kidney, liver and uterus tested with hyperimmune serum against serovar Hardjo were negative.
\end{abstract}

Key words: Leptospire, indirect immunoperoxidase, immunohistochemistry, cows, culture

\section{INTRODUCTION}

Bovine leptospirosis is a worldwide distributed infection, responsible for great losses in bovine breeding due to abortion, stillbirth or weak calves, reduction in fertility rates and decrease in milk production (12). Leptospiral serovars that affect bovines more frequently are Hardjo, Pomona, Canicola and Icterohaemorrhagiae. Nowadays, serovar Hardjo is considered the most frequent and important serovar for bovines $(4,6,11)$. Due to the persistence of this serovar in kidneys, infected bovines may eliminate leptospires in urine for up to 542 days after infection (25). In infections caused by serovar Hardjo, the genital tract of cows and heifers may also be affected. This site of infection may be as important as the kidney (9).

Laboratory routine diagnosis of bovine leptospirosis is performed using serological methods and leptospires detection in urine and organs. Detection of leptospire in different organs may be performed by immunohistochemistry techniques, which use the interaction antigen-antibody and enzymatic markers $(13,15,29)$. Among these assays, those that use peroxidase have some advantages, such as low cost and the possible visualization of the reactions both in optical and electronic microscope. Immunoperoxidase also enables the observation of leptospires in histological preparations. Thus, fragments fixed in

*Corresponding Author. Mailing address: Universidade Estadual de Londrina, Centro de Ciências Agrárias, Departamento de Medicina Veterinária Preventiva. Rodovia Celso Garcia Cid (PR445), Km 380, Caixa Postal 6001. 86051-990, Londrina, PR, Brasil. Tel.: (+5543) 3371-4765, Fax: (+5543) 3371-4714. E-mail: freitasj@uel.br 
formaldehyde may simultaneously show the agent and the microscopic lesions caused by it $(12,18,28)$. Scanziani et al. (18) used the indirect immunoperoxidase assay in the diagnosis of swine leptospirosis and reported sensitivity and specificity of assay to be, respectively, of $78 \%$ and $100 \%$. A positive result in the immunoperoxidase assay is directly related to the number of leptopires in the histological preparation under examination (6). Scanziani et al. (18) observed that the sensitivity of the immunoperoxidase assay may be enhanced when more than one histological section is used per animal.

The objective of this trial was to detect leptospires using different tests in cows slaughtered in Paraná state, Brazil.

\section{MATERIALS AND METHODS}

Samples were collected from January to December 2001, from 96 females of unknown sanitary status, randomly chosen at slaughter in a slaughterhouse in Paraná state, Brazil.

Urine, kidney, liver and uterus samples were collected around 10 minutes after animals were slaughtered. Approximately $3 \mathrm{~mL}$ of urine were collected from each animal by direct bladder puncture. Fragments of kidney, liver and uterus, without any visible macroscopic lesion, were collected on slaughterhouse eviscerating table. These fragments were then cut into two new fragments of around $1 \mathrm{~cm}^{3}$ each. One of them was placed in transport medium containing $1 \%$ bovine seroalbumin in phosphate buffer saline (PBS pH 7.4) (24). The other fragment was fixed in $10 \%$ buffered formaldehyde. Samples collected were sent to the Leptospirosis Laboratory at Department of Veterinary Preventive Medicine (DMVP) at the State University of Londrina (UEL)/ PR, Brazil, and processed around two hours after collection.

Urine samples were submitted to direct examination using a dark field microscope. One drop of urine per animal was placed on a glass slide and covered with a coverslip. The material was examined by optical microscope (Olympus ${ }^{\circledR}$ - Model Bx40) at 200x magnification. A positive result was made by visualization of cells presenting morphology and motility compatible with leptospires (11).

EMJH (Difco ${ }^{\circledR}$-USA) and Tween 80/40/LH (8) culture media were used in the isolation of the Leptospira spp. EMJH was added of $10 \%$ rabbit serum enriched with L-asparagine, sodium piruvate, calcium chloride and magnesium chloride (1). Modified EMJH and Tween 80/40/LH were both prepared in two formulations, one without antibiotics and the other, added of 5fluorouracil (400 mg/L; Sigma ${ }^{\circledR}$-USA) (16) and chloranphenicol (5 mg/L; Sigma $\left.{ }^{\circledR}-U S A\right)$, nalidixic acid (50 mg/L; Inlab $\left.{ }^{\circledR}-\mathrm{BR}\right)$, neomycin $\left(10 \mathrm{mg} / \mathrm{L}\right.$; Sigma ${ }^{\circledR}$-USA $)$ and vancomycin $(10 \mathrm{mg} / \mathrm{L}$; $\operatorname{Acros}^{\circledR}$-USA) (20).

In the isolation procedure, positive samples in the direct examination were cultured in duplicate in modified EMJH and Tween $80 / 40 / \mathrm{LH}$ added of antibiotics and incubated at $28^{\circ} \mathrm{C}$ for
24 hours. After this time, subcultures were performed, in duplicate, in the respective media, without antibiotics. Cultures were assessed weekly, for up to 16 weeks (10). The cultures were examined by optical microscope (Olympus ${ }^{\circledR}$ - Model Bx 40 ) at 200x magnification. Kidney, liver and uterus samples in transport medium were tritured and diluted $\left(10^{-1}-10^{-3}\right)$ in sterile PBS ( $\mathrm{pH}$ 7.4). From these dilutions, the same cultivation methodology was carried out as used for the urine samples. Inoculum used for isolation and subcultures corresponded to $10 \%$ of the volume of the culture medium cultured.

Two female adult rabbits, weighting 3 to $3.5 \mathrm{~kg}$ were used for the production of hyperimmune serum against serovar Hardjo (Hardjoprajitno). They were infected with serial inoculations of leptospire cultures in the marginal ear vein. Seven-day old cultures were used as inoculum. Each animal was inoculated with successive doses equal to 1, 2, 4, 6 and again $6 \mathrm{~mL}$ of leptospire culture at seven-day intervals. After one week of the last inoculation, blood samples were collected and sera tested in the microscopic seroagglutination test. Titers homologous to 51,200 were detected and the rabbits were bled by heart puncture. Sera obtained were stored in aliquots equal to $500 \mu \mathrm{L}$ at $-20^{\circ} \mathrm{C}(12,17)$.

Hyperimmune serum against the local strain Londrina 14 (LO14), serovar Canicola, typing by pulsed-field electrophoresis (Center for Disease Control - USA), which was isolated from the urine of a female slaughtered in the northern region of Paraná state, Brazil, was used. This hyperimmune serum was produced according to the method described above, and presented homologous titer equal to 25,600.

At the Laboratory of Veterinary Pathology of DMVP-UEL, kidney, liver and uterus fragments were fixed in $10 \%$ buffered formaldehyde for 72 hours and embedded in paraffin. From these fragments, sections cut $(5 \mu \mathrm{m})$ thick were obtained and stained by $\mathrm{HE}$ (3), and indirect immunoperoxidase (5).

In the indirect immunoperoxidase assay, hyperimmune sera against serovar Hardjo and strain LO14 were used as primary antibodies. These sera were diluted to 1:100, 1:200, 1:300, 1:400 and 1:500. The dilutions chosen were 1:300 and 1:200 to serovar Hardjo and to strain LO14 respectively, once these dilutions shown the best stain without unspecific precipitate. Swine antirabbit immunoglobulin marked with peroxidase (Dako ${ }^{\circledR}$-USA) was used as secondary antibody, diluted 1:200. Reaction was shown by tetra-hydrochloride diaminobenzidine substratesolution (Dako ${ }^{\circledR}$-USA) in hydrogen peroxide (Synth ${ }^{\circledR}$-BR) and counterstained with hematoxylin (5). For each sample tested, a negative control was used, in which Tris-PBS ( $\mathrm{pH} 7.4)$ replaced the primary antibody. As positive controls, sections cut of the kidney of one of the rabbits inoculated with serovar Hardjo, and the kidney of the bovine, which strain LO14 was isolated. Reading was carried out by optical microscope (Olympus ${ }^{\circledR}$ model $\mathrm{CH} 30$ ) at 400x magnification. Positive results were characterized by the visualization of brown structures compatible with leptospires. 


\section{RESULTS}

From 96 urine samples submitted to direct examination in the dark field microscope, four were positive. The number of leptospires observed per field (200x) in each urine sample ranged from 3 to 20 cells. All of them presented normal motility.

In all urine, kidney, liver and uterus samples cultured did not occur isolation during 16 weeks of incubation. The growth of contaminant microorganisms occurred in only five liver samples.

Most frequently histological alteration observed in kidney fragments was focal interstitial infiltrate of mononuclear cells. No changes suggestive of leptospirosis were observed in the fragments of liver and uterus analyzed.

Indirect immunoperoxidase assay performed using hyperimmune serum against strain LO14 showed positive results in the kidney of one animal (Fig. 1), characterized by the visualization of leptospires stained in intense brown in the lumen of renal tubules. Liver and uterus of this animal were not positive. Indirect immunoperoxidase assay using hyperimmune serum against serovar Hardjo presented negative results in all histological sections tested (Table 1).

\section{DISCUSSION}

Urine of four cows showed viable leptospires, indicating the presence of this microorganism in the kidney of these animals. The elimination of leptospires in the urine may be intermittent or continuous. The absence of leptospires in urine does not exclude the possibility of colonization of other sites, such as kidney, liver and uterus (12).

The main histological changes observed in bovine leptospirosis are observable in the kidneys. These lesions may range from not extensive inflammatory infiltrates to diffuse

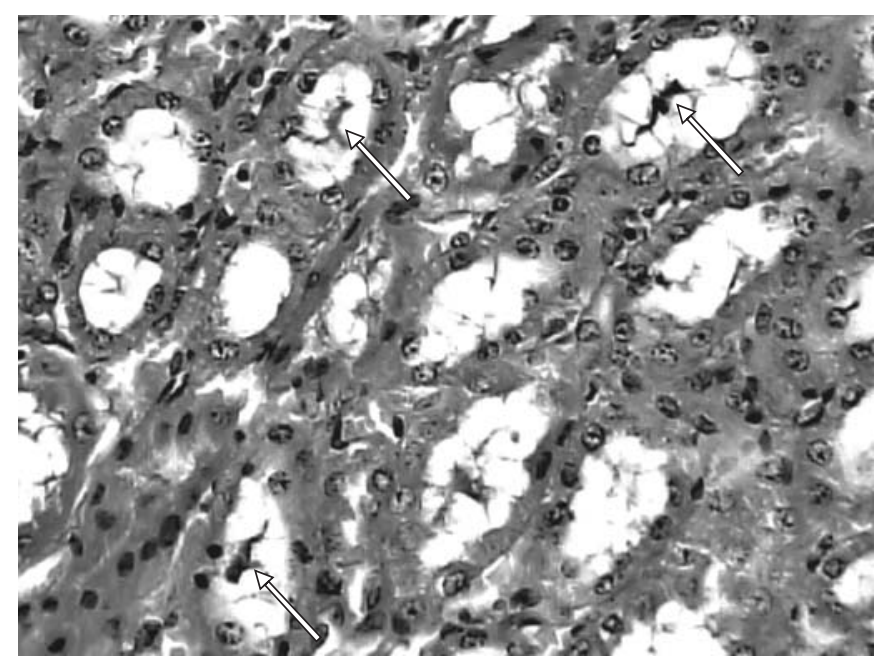

Figure 1. Photomicrograph of the kidney of a positive cow submitted to indirect immunoperoxidase assay. Leptospires are visible in the lumen of renal tubules (arrows). Indirect immunoperoxidase, haematoxylin counterstain. X400.

lesions, characterized by cell necrosis, tubular atrophy and renal haemorrhage $(2,11)$. Most of the animals studied presented changes suggestive of leptospirosis in the histopathological examination of the kidneys stained by HE. However, lesions were discrete, including in animals that presented positive results in the direct examination of their urine. Skilbeck et al. (22) did not observe significant lesions in bovine kidneys from which leptospires were isolated. Tissue lesions caused by these microorganisms are related to the infecting serovar and the immunological response by the host (12). Baskervile (2) stated

Table 1. Results of samples collected from 96 cows slaughtered in Paraná, Brazil, from January to December, 2001, and submitted to laboratory exams used in leptospirosis diagnosis according to the identification of the animal, type of exam and nature of the results. Londrina, 2003.

\begin{tabular}{|c|c|c|c|c|c|}
\hline \multirow{3}{*}{ Animal } & \multicolumn{5}{|c|}{ Results of laboratory exams } \\
\hline & \multirow[t]{2}{*}{$\begin{array}{l}\text { Direct urine } \\
\text { examination }\end{array}$} & \multicolumn{2}{|c|}{$\begin{array}{c}\text { Indirect } \\
\text { immunoperoxidase* }\end{array}$} & \multirow[t]{2}{*}{ Culture** } & \multirow[t]{2}{*}{ Histopathological examination* } \\
\hline & & LO14 & hardjo & & \\
\hline a & + & $++^{\beta}$ & - & - & $\begin{array}{l}\text { Periglomerular, perivascular and interstitial } \\
\text { mononuclear cell infiltrate }^{\beta}\end{array}$ \\
\hline $\mathrm{b}$ & + & - & - & - & Interstitial mononuclear cell infiltrate ${ }^{\beta}$ \\
\hline $\mathrm{c}$ & + & - & - & - & No histological alteration \\
\hline $\mathrm{d}$ & + & - & - & - & Interstitial and perivascular mononuclear cell infiltrate ${ }^{\beta}$ \\
\hline $92 * * *$ & - & - & - & - & Most animals presented interstitial mononuclear cell infiltrate ${ }^{\beta}$ \\
\hline
\end{tabular}

+ positive; - negative; * kidney, liver and uterus; ** urine, kidney, liver and uterus; *** other females; ${ }^{\beta}$ only in kidney. 
that histological changes visualized by HE may be unspecific and this technique should be associated with other assays.

Indirect immunoperoxidase has been used in the detection of leptospires in organs $(15,19,26,29)$. Scanziani et al. (18) reported that positive predictive value of immunoperoxidase assay is $100 \%$ and negative predictive value $80 \%$. Thus, false negative results are therefore to be expected, since leptospires may be present in areas other than the histological section examined. They also stated that the sensitivity of the assay may be enhanced by using more than one histological section per organ.

Indirect immunoperoxidase assays were performed using hyperimmune sera against serovar Hardjo and strain LO14 (serovar Canicola). Nowadays, serovar Hardjo is the most frequent and important serovar affecting bovines $(6,12,14)$. Strain LO14 was isolated from a cow in the northern region of Paraná state and could be one of the regionally prevalent serovars. The assay performed with hyperimmune serum against strain LO14 detected leptospires in the kidney of only one animal. Liver and uterus of this animal were negative in the assay. This result is probably related to the infecting serovar and the phase of the disease. The persistence of serovars from serogroup Canicola in the reproductive system of bovines has not been recognized. During the acute phase of the disease, especially the liver is affected by leptospires. However, around 10 days after infection, specific antibodies appear, and remove the microorganism from the liver and most affected organs (12).

Due to the importance of serovar Hardjo in bovines, positive results were expected in the indirect immunoperoxidase assay performed using hyperimmune serum against this serovar, mainly in the kidney and uterus of the animals that were positive in the direct examination of urine. According to Ellis and Michna (7) and Ellis et al. (9), serovar Hardjo may persist for long periods in the renal tissue and genital tract of bovines. In spite of serological results $(12,27)$ which indicates that serovar Hardjo is the most prevalent in bovines, there are no reports of the isolation of this serovar in the region studied.

Cross-reactions of hyperimmune sera (polyclonal antibodies) may be observed in the indirect immunoperoxidase assay, what enables the detection of a greater number of leptospira serovars $(18,28)$. However, in the present trial, no cross-reaction was observed in the histological sections used as controls for hyperimmune sera against serovar Hardjo and strain LO14, neither in sections cut of the kidney of the animal positive for strain LO14. Ellis et al. (5) did not observe crossreactions in the indirect immunoperoxidase assay using hyperimmune serum against serovars Tarassovi, Hardjo and Pomona in swine kidneys naturally infected with serovar Pomona. The possibility of infection by other serovars than those used in the immunoperoxidase assay cannot be ruled out in the present trial, mainly in the animals that presented positive results in the direct examination of urine. Silva (21) isolated leptospires from the urine of two bovines in the northern region of Paraná state. One of them was preliminarily typing as belonging to the serogroup Australis and the other, to serogroup Icterohaemorrhagiae.

Although leptospires are difficult to be isolated, their growth was expected in the urine samples positive by direct examination and in the kidney sample positive by indirect immunoperoxidase assay. Several factors not determined in the present study may have prevented the growth of the microorganism in the material cultured. For example, acid $\mathrm{pH}$ of urine, the presence of specific antibodies, the occurrence of contaminating microorganisms, among other factors, directly interfere with the growth of leptospires and may prevent their isolation $(12,23)$.

\section{RESUMO}

\section{Detecção de leptospiras em rim, fígado e útero de fêmeas bovinas abatidas no estado do Paraná, Brasil}

O objetivo deste trabalho foi detectar leptospiras em fragmentos de rim, fígado e útero de 96 fêmeas bovinas com histórico sanitário desconhecido, escolhidas aleatoriamente durante o abate em um frigorífico no Estado do Paraná, Brasil. Todas as 96 amostras de urina foram submetidas ao exame direto em microscópio de campo escuro. As amostras positivas neste exame e todos os fragmentos de rim, fígado e útero foram semeados nos meios de cultura EMJH modificado e Tween 80/40/LH. Os cortes histológicos de rim, fígado e útero foram submetidos à coloração de Hematoxilina-Eosina (HE) e a prova de imunoperoxidase indireta com soros hiperimunes contra o sorovar Hardjo (Hardjoprajitno) e contra a estirpe Londrina (LO14), do sorovar Canicola, isolada no norte do Paraná, Brasil, utilizados como anticorpo primário. O exame direto detectou leptospiras na urina de quatro animais. Todas as tentativas de isolamento das urinas e fragmentos de rim, fígado e útero foram negativas após 16 semanas de incubação. No exame histopatológico foi observado infiltrado focal de células mononucleares no interstício renal da maioria dos animais. Na prova de imunoperoxidase indireta com o soro hiperimune contra a estirpe LO14, o rim de um animal foi o único a apresentar resultado positivo. Todos os fragmentos de rim, fígado e útero testados com o soro hiperimune contra o sorovar Hardjo foram negativos.

Palavras-chave: Leptospira, imunoperoxidase indireta, imunohistoquímica, bovino, cultura

\section{REFERENCES}

1. Alves, C.J. Influência de fatores ambientais sobre a proporção de caprinos soro-reatores para leptospirose em cinco centros de criação do Estado da Paraíba, Brasil. São Paulo, 1995, 104 p. (Ph.D Thesis. Faculdade de Medicina Veterinária e Zootecnia. Universidade de São Paulo). 
2. Baskervile, A. Histopathological aspects of diagnosis of leptospirosis. In: Ellis, W.A.; Little, T.W.A. (eds). The present state of leptospirosis diagnosis and control. Northern Ireland, 1986, p.33-43.

3. Behmer, O.A.; Tolosa, E.M.C. de; Freitas Neto, A.G. de Manual de técnicas para histologia normal e patológica. São Paulo: EDART, 1976. $241 \mathrm{p}$.

4. Dhaliwal, G.S.; Murray, R.D.; Ellis, W.A. Reproductive performance of dairy herds infected with Leptopira interrogans serovar hardjo relative to the year of diagnosis. Vet. Rec., 138, 272-276, 1996.

5. Ellis, T.M.; Robertson, G.M.; Hustas, L.; Kirby, M. Detection of leptospires in tissue using an immunoperoxidase staining procedure. Aust. Vet. J., 60, 364-67, 1983.

6. Ellis, W.A. Leptospirosis as a cause of reproductive failure. Vet. Clin. Nor. Am.: Food Animal Practice., 10, 463-478, 1994.

7. Ellis, W.A.; Michna, S.W. Bovine leptospirosis: experimental infection of pregnant heifers with a strain belonging to the Hebdomadis serogrup. Res. Vet. Sci., 22, 229-236, 1977.

8. Ellis, W.A.; Montgomery, J.; Cassells, J.A. Dihydrostreptomycin treatment of bovine carriers of Leptospira interrogans serovar hardjo. Res. Vet. Sci., 39, 292-295, 1985.

9. Ellis, W.A.; O’Brien, J.J.; Cassells, J.A.; Neill, S.D.; Hanna, J. Excretion of Leptospira interrogans serovar hardjo following calving or abortion. Res. Vet. Sci., 39, 296-298, 1985.

10. Ellis, W.A.; O’Brien, J.J.; Neill, S.D.; Ferguson, H.W.; Hanna, J. Bovine leptospirosis: Microbiological and serological findings in aborted fetuses. Vet. Rec., 110, 147-150, 1982.

11. Faine, S. Guidelines for the control of leptospirosis. Geneva: World Health Organization. 1982, 171p. (WHO Offset Publication 67).

12. Faine, S.; Adler, B.; Bolin, C.; Perolat, P. Leptospira and Leptospirosis. 2 ed. Melbourne: Medisci, 1999, 272p.

13. Gimeno, E.J; Massone, A.R.; Portiansky, E.L. Introducción a las técnicas de inmunohistoquímica y aplicaciones en patología veterinaria. Octavo curso internacional de posgrado en técnicas de inmunohistoquímica, lectinhistoquímica y microscopia electrónica. La Plata, 1997, 49-77.

14. Grégoire, N.; Higgins, R.; Robinson, Y. Isolation of leptospires from nephritic kidneys of beef cattle at slaughter. Am. J. Vet. Res., 48, 370-371, 1987.

15. Haanwinckel, M.C.S. Avaliação da prova de imunoperoxidase indireta como recurso diagnóstico na leptospirose. Botucatu, 2000, 83p. (M.Sc. Thesis. Faculdade de Medicina Veterinária e Zootecnia. Universidade Estadual Paulista "Júlio de Mesquita Filho").

16. Herr, S.; Riley, A.E.; Neser, J.A.; Roux, D.; De Lange, J.F. Leptospira interrogans sorovar pomona associated with abortion in cattle: isolation methods and laboratory animal histopathology. Onderstepoort J. Vet. Res., 49, 57-62, 1982.

17. Santa Rosa, C.A. Diagnóstico Laboratorial das Leptospiroses. Rev. Microbiol., 1, 97-109, 1970.

18. Scanziani, E.; Luini, M.; Fabbi, M.; Pizzocaro, P. Comparison between specifc immunoperoxidase staining and bacteriological culture in the diagnosis of renal leptospirosis of pigs. Res. Vet. Sci., 50, 229232, 1991.

19. Scanziani, E.; Sironi, G.; Mandelli, G. Imunoperoxidase studies on leptospiral nephritis of swine. Vet. Pathol., 26, 442-444, 1989.

20. Schönberg, A. Studies on the effect of antibiotic substances on leptospires and their cultivation from material with a high bacterial count. Zbl. Bakt. Hyg., 249, 400-406, 1981.

21. Silva, F.G. Diagnóstico da leptospirose pelo isolamento e prova de imunoperoxidase indireta em materiais biológicos de bovinos abatidos em frigoríficos do Estado do Paraná. Londrina, 2003, 71p. (M.Sc. Thesis. Centro de Ciências Agrárias. Universidade Estadual de Londrina).

22. Skilbeck, N.W.; Forsyth, W.M.; Dohnt, M. Bovine leptospirosis: Microbiological and histological findings in cattle at slaughter. Aust. Vet. J., 65, 73-75, 1988.

23. Smith, C.R.; Ketterer, P.J.; Corney, B.G. A review of laboratory techniques and their use in the diagnosis of Leptospira interrogans serovar hardjo infection in cattle. Aust. Vet. J., 71, 290-294, 1994.

24. Thiermann, A.B. Canine leptospirosis in Detroit. Am. J. Vet. Res., 41, 1659-1661, 1980.

25. Thiermann, A.B. Bovine leptospirosis: Experimental leptospiral infections in pregnant cattle with organisms of the Hebdomadis serogroup. Am. J. Vet. Res., 43, 780-784, 1982.

26. Tripathy, D.N.; Hanson, L.E. Immunoperoxidase staining of leptospires. Appl. Microbiol., 27, 268-269, 1974.

27. Vasconcellos, S.A.; Barbarini Jr, O.; Umehara, O.; Morais, Z.M.; Cortez, A.; Pinheiro, S.R.; Ferreira, F.; Fávero, A.C.M.; Fereira Neto, J.S. Leptospirose bovina. Níveis de ocorrência e sorotipos predominantes em rebanhos dos estados de Minas Gerais, São Paulo, Rio de Janeiro, Paraná, Rio Grande do Sul e Mato Grosso do Sul. Período de janeiro a abril de 1996. Arq. Inst. Biol. (S. Paulo), 64, 7-15, 1997.

28. Zamora, J.; Riedemann, S.; Cabezas, X.; Vega, S. Comparación de cuatro técnicas microscópicas para el diagnóstico de leptospirosis en roedores silvestres en el area rural de Valdivia, Chile. Rev. Lat. Amer. Microbiol., 37, 267-272, 1995.

29. Yener, Z.; Keles, H. Imunoperoxidase and histopathological examinations of leptospiral nephritis in cattle. J. Med. A. Physiol. Clin. Med., 48, 441-447, 2001. 